Online: http://journal.uny.ac.id/index.php/jppfa

\title{
MODEL KURIKULUM PENDIDIKAN MULTIKULTURAL DI TAMAN KANAK-KANAK
}

\author{
M. Fadlillah \\ PG-PAUD Universitas Muhammadiyah Ponorogo \\ fadly_ok@yahoo.co.id
}

\begin{abstract}
Abstrak
Artikel ini bertujuan untuk mengetahui: (1) konsep kurikulum pendidikan multikultural di Taman Kanak-Kanak, dan (2) model pengembangan kurikulum pendidikan multikultural di Taman Kanak-Kanak. Penelitian ini menggunakan metode kualitatif deskriptif. Pengumpulan data dilakukan dengan teknik wawancara, observasi, dan dokumentasi terhadap kegiatan pembelajaran di Taman Kanak-Kanak. Penelitian ini berhasil menemukan bahwa: (1) konsep kurikulum pendidikan multikultural di Taman Kanak-Kanak merupakan bentuk kurikulum yang memuat materi-materi pendidikan multikultural yang diperuntukkan bagi pembelajaran anak usia dini dalam rangka mengenalkan dan menanamkan sikap kebersamaan, keadilan, dan toleransi pada diri anak. (2) model pengembangan kurikulum pendidikan multikultural di Taman Kanak-Kanak dilakukan dengan menggunakan empat pendekatan, yaitu pendekatan kontribusi, aditif, transformasi, dan aksi sosial. Dari keempat pendekatan tersebut yang dapat diterapkan dalam pendidikan anak usia dini hanya ada dua, yakni: pendekatan kontribusi dan pendekatan aditif.
\end{abstract}

Kata kunci: kurikulum, pendidikan multikulturan, taman kanak-kanak.

\section{THE MODEL OF MULTICULTURAL EDUCATION CURRICULUM IN KINDERGARTEN}

\author{
M. Fadlillah \\ PG-PAUD Universitas Muhammadiyah Ponorogo \\ fadly_ok@yahoo.co.id
}

\begin{abstract}
This article aims to know: (1) The concept of multicultural education curriculum in kindergarten, and (2) The model of multicultural education curriculum. This study method used descriptive qualitative method. The collecting data was done by interview, observation and documentation of learning activities in the kindergarten. This study resulted the findings that: (1) The concept of multicultural education curriculum in kindergarten as a form of curriculum contains the materials of multicultural education which given to the learning of the childhood in order to introduce and inculcate unity, justice, and tolerance in children. (2) The model of curriculum development of multicultural education in kindergarten is done by using four approaches, namely the contrivution of additives, transformation, and social action. From the four approaches that can be applied in early childhood education, there are only two, namely the contribution approach and additive approach.
\end{abstract}

Keywords: curriculum, multicultural education, kindergarten 


\section{PENDAHULUAN}

Pendidikan multikultural saat ini mempunyai kedudukan yang sangat penting bagi bangsa Indonesia. Selain untuk memperkuat persatuan dan kesatuan, pendidikan multikultural juga berfungsi sebagai sarana menanamkan sikap toleran, adil, dan santun pada diri anak. Dengan adanya pendidikan multukultural ini, diharapkan tidak ada lagi tindakan-tindakan diskriminasi, konflik, dan segala bentuk permusuhan lainnya. Menurut data dari Badan Pusat Statistik pada tahun 2008, 2011, dan 2014 memperlihatkan kecenderungan peningkatan jumlah dan persentase desa/kelurahan yang mengalami perkelahian massal. Jumlah desa/kelurahan yang mengalami kejadian perkelahian massal selama setahun terakhir periode sensus terus meningkat dari $2.283 \mathrm{desa} /$ kelurahan pada tahun 2008 menajdi 2.562 desa/keluarahan pada tahun 2014. Secara persentase dibandingkan jumlah total desa/kelurahan terus meningkat dari 3,03 persen menjadi 3,38 persen pada tahun 2014.

Data tersebut menunjukkan bahwa pendidikan multikultural mempunyai peranan penting di masyarakat. Oleh karena itu, pendidikan multikultural sangat tepat diberikan kepada masyarakat di Indonesia, mulai dari kalangan anak-anak, remaja, pemuda sampai pada orang dewasa. Hal ini dimaksudkan supaya berbagai konflik yang terjadi di berbagai daerah dapat segara teratasi atau minimal berkurang intensitasnya.

Terkait hal tersebut, salah satu cara yang dianggap paling efektif dalam menanamkan nilai-nilai pendidikan multikultural ialah melalui lembaga-lembaga pendidikan, lebihlebih dimulai sejak dari Taman Kanak-Kanak. Anggapan ini memang ada benarnya, sebab aktivitas anak sehari-hari berlangsung di sekolah. Selain itu, pada usia taman kanakkanak, seorang anak lebih mudah untuk menerima berbagai informasi baru dan kemudian mengaplikasikannya dalam kehidupannya sehari-hari. Hasil penelitian menunjukkan sekitar 50\% kapabilitas kecerdasan manusia terjadi ketika berumur 4 tahun, $80 \%$ telah terjadi ketika berumur 8 tahun, dan mencapai titik kulminasi ketika anak berumur sekitar 18 tahun (Wahyudin \& Agustin, 2011, p. 2). Artinya, dengan perkembangan otak yang luar biasa ini, anak usia dini memiliki potensi untuk diberikan bekal pendidikan multikul- tural dengan lebih mudah dan belum banyak terpengaruh dengan dunia luar.

Namun yang menjadi persoalan sekarang ini adalah banyak guru maupun sekolah yang merasa kesulitan menerapkan pendidikan multikultural di sekolah. Salah satu penyebab utamanya ialah belum adanya kurikulum pendidikan multikultural yang dapat dijadikan sebagai pedoman dalam pembelajaran. Padahal untuk dapat mengimplementasikan pendidikan multikultural dengan maksimal dibutuhkan adanya kurikulum yang jelas. Hal ini dikarenakan kurikulum mempunyai peranan yang cukup vital dalam dunia pendidikan. Menurut Hamalik (2007) kurikulum memiliki beberapa peranan utama, yaitu: (1) peranan konservatif, yakni untuk mewariskan, mentransmisikan, dan menafsirkan nilai-nilai sosial dan budaya masa lampau yang tetap eksis dalam masyarakat; (2) peranan kritis dan evaluatif, yakni untuk menilai dan memilih nilai-nilai sosial budaya yang akan diwariskan kepada peserta didik berdasarkan kriteria tertentu; dan (3) peranan kreatif, yakni untuk menciptakan dan menyusun kegiatan-kegiatan yang kreatif dan konstruktif sesuai dengan perkembangan peserta didik dan kebutuhan masyarakat. Di samping itu, kurikulum berfungsi sebagai alat untuk mencapai tujuantujuan yang diinginkan dan sekaligus sebagai pedoman dalam mengatur segala kegiatan pendidikan setiap hari (Hidayat, 2013, pp. 2526).

Berdasarkan persoalan-persoalan tersebut, maka dalam artikel ini akan menguraikan tentang konsep kurikulum pendidikan multikultural di Taman Kanak-Kanak dan karakteristik model kurikulum pendidikan multikultural di Taman Kanak-Kanak. Semua-nya dimaksudkan sebagai usulan alternatif kurikulum pendidikan anak usia dini di Indonesia.

\section{METODE PENELITIAN}

Penelitian ini menggunakan metode kualitatif deskriptif, yaitu sebuah penelitian yang menggambarkan kondisi secara alamiah (Sugiyono, 2011, pp. 8-9). Metedo ini dimaksudkan untuk menggambarkan secara umum kurikulum dan kegiatan pembelajaran di Taman Kanak-Kanak. Untuk pengumpulan data dalam penelitian ini dilakukan dengan menggunakan tiga cara, yaitu observasi, wawancara, dan dokumentasi. Ketiga teknik pe- 
ngumpulan data tersebut digunakan untuk mengumpulkan berbagai informasi yang terkait dengan kurikulum pendidikan multikultural dan kegiatan pembelajaran di Taman Kanak-Kanak. Adapun yang menjadi subjek penelitian ini, meliputi: kepala sekolah, guru, dan siswa di Taman Kanak-Kanak di Kabupaten Ponorogo.

\section{PEMBAHASAN}

\section{Kurikulum Taman Kanak-Kanak}

Pengertian Kurikulum

Kurikulum merupakan sebuah wadah yang akan menentukan arah pendidikan. Berhasil dan tidaknya sebuah pendidikan sangat bergantung pada kurikulum yang digunakan. Kurikulum adalah ujung tombak bagi terlaksananya kegiatan pendidikan (Fadlillah, 2014, p. 2). Tanpa adanya kurikulum mustahil pendidikan dapat berjalan dengan baik, efektif dan efisien sesuai yang diharapkan.

Secara etimologi pengertian kurikulum berasal dari beberapa bahasa. Dalam bahasa Yunani istilah kurikulum berasal dari kata curir yang artinya pelari dan curere yang berarti tempat berpacu, sedangkan dalam bahasa Perancis, kurikulum diambil dari kata courir yang berarti berlari (to run) (Arifin, 2014, p. 2). Adapun secara terminologi kurikulum pada zaman Romawi kuno diartikan sebagai jarak yang harus ditempuh oleh seorang pelari dari garis star sampai garis finish untuk memperoleh medali atau penghargaan (Hidayat, 2013, p. 19). Selanjutnya, pengertian kurikulum tersebut dipakai dalam dunia pendidikan mulai tahun 1855. Jarak yang harus ditempuh oleh seorang pelari tersebut dalam dunia pendidikan kemudian dinamakan sebagai kurikulum, yaitu seperangkat rencana yang berisi berbagai kegiatan yang harus dilalui oleh peserta didik selama menempuh pendidikan di sekolah.

Menurut Saylor, Alexander, dan Lewis (Rusman, 2011, p. 3) mengartikan kurikulum sebagai segala upaya sekolah untuk memengaruhi siswa agar dapat belajar, baik dalam ruangan kelas maupun di luar sekolah. Sementara itu, Harorld B. Alberty memandang kurikulum sebagai semua kegiatan yang diberikan kepada siswa di bawah tanggung jawab sekolah. Dari pengertian tersebut kuriku- lum diartikan hanya sebatas kegiatan untuk peserta didik yang dibuat oleh sekolah sebagai upaya untuk mencapai tujuan pembelajaran. Kurikulum di sini hanya memuat sejumlah mata pelajaran yang harus ditempuh oleh setiap peserta didik. Oleh karena tujuan akhir dari proses pendidikan ini ialah erat hubungannya dengan memperoleh ijazah.

Pendapat lain dikemukakan oleh Hamalik (2007) yang menjelaskan bahwa kurikulum adalah program pendidikan yang disediakan oleh lembaga pendidikan (sekolah) bagi siswa. Adapun Hilda Taba (Sanjaya, 2008, p. 7) menyebutkan: 'A curriculum ia a plan for learning; therefore, what is known about the learning process and the development of the individual has bearing on the shaping of a curriculum'. Maksudnya yaitu kurikulum merupakan perencanaan pembelajaran yang memuat berbagai petunjuk belajar serta hasil yang diharapkan.

Selanjutnya, dalam Undang-Undang Nomor 20 Tahun 2003 tentang Sistem Pendidikan Nasional (Depdiknas, 2003) disebutkan bahwa kurikulum ialah seperangkat rencana dan pengaturan mengenai isi dan bahan pelajaran serta cara yang digunakan sebagai pedoman penyelenggaraan kegiatan belajar mengajar. Apabila dikaitkan dengan Taman Kanak-Kanak, kurikulum ini dapat diartikan sebagai seperangkat rencana dan pengaturan mengenai isi dan bahan pelajaran yang dapat digunakan sebagai pedoman dalam penyelenggaraan kegiatan pembelajaran pada level anak usia dini.

National Asociation Early Child Years (NAECY) memberikan batasan kurikulum Taman Kanak-Kanak, yaitu: (a) kurikulum berisi materi yang dipelajari anak; (b) kurikulum adalah proses yang diikuti oleh anak mencapai tujuan yang ditetapkan; (c) kurikulum berisi dukungan guru kepada anak untuk mencapai tujuan; (d) Kurikulum merupakan perpaduan proses belajar dan mengajar.

Melihat berbagai urain pengertian tersebut, maka kurikulum Taman Kanak-Kanak memiliki cakupan yang sangat luas. Sebagaimana disebutkan dalam Permendikbud No. 146 Tahun 2014 bahwa muatan kurikulum PAUD (Mendikbud, 2014) meliputi: tujuan, hasil belajar, proses, konten yang sesuai dengan tingkat perkembangan anak untuk membangun pengetahuan, keterampilan, dan sikap yang diperlukan untuk mendukung kesiapan 
anak belajar di jenjang pendidikan yang lebih lanjut.

\section{Fungsi Kurikulum}

Berkaitan dengan fungsi kurikulum dalam pendidikan dapat ditinjau dari berbagai aspek, mulai dari sekolah, pengawas, sampai pada masyarakat. Adapun secara keseluruhan fungsi kurikulum dapat diidentifikasi sebagai berikut: (1) sebagai alat untuk mencapai tujuan-tujuan yang diinginkan; (2) sebagai pedoman dalam mengatur segala kegiatan pendidikan setiap hari; (3) sebagai pedoman bagi guru dalam melaksanakan program pembelajaran supaya bisa mencapai tujuan pendidikan; (4) sebagai pedoman kepala sekolah dalam mengukur keberhasilan program pendidikan di sekolah yang dipimpin; (5) sebagai pedoman bagi pengawas dalam melaksanakan supervisi pendidikan; (6) Sebagai pedoman bagi masyarakat dalam memberikan bantuan guna memperlancar pelaksanaan program pendidikan di tingkat satuan pendidikan (Hidayat, 2013, pp. 25-31).

Dengan memperhatikan fungsi kurikulum tersebut, dapat dipahami bahwa kurikulum memiliki peranan utama terhadap terlaksananya pendidikan multikultural di Taman Kanak-Kanak. Oleh karena itu, untuk dapat melaksanakan pendidikan multikultural di Taman Kanak-Kanak harus dimulai dengan pengembangan kurikulumnya.

\section{Pendidikan Multikultural}

\section{Pengertian Pendidikan Multikultural}

Istilah pendidikan multikultural merupakan gabungan dari dua unsur kata yaitu pendidikan dan multikultural. Kedua kata tersebut akan diuraikan satu persatu sebelum mendefinisikan secara keseluruhan pendidikan multikultural. Hal ini dimaksudkan supaya konsep pendidikan multikultural dapat dipahami secara mendasar.

Makna pendidikan merupakan terjemahan dari education, yang kata dasarnya $e d u$ cate atau bahasa latinnya educo. Educo berarti mengembangkan dari dalam; mendidik; melaksanakan hukum kegunaan (Sutrisno, 2011, p. 3). Ada pula yang mengatkan bahwa kata education berasal dari bahasa latin educare yang memiliki konotasi melatih atau menjinakkan (seperti dalam konteks manusia me- latih hewan-hewan yang liar menjadi semakin jinak, sehingga bisa diternakkan), dan menyuburkan (membuat tanah lebih menghasilkan banyak buah berlimpah karena tanhnya telah digarap dan diolah) (Koesoema, 2011, p. 53).

Menurut konsep tersebut pendidikan merupakan sebuah proses yang membantu menumbuhkan, mengembangkan, mendewasakan, membuat yang tidak tertata atau liar menjadi semakin tertata, semacam proses penciptaan sebuah kultur dan tata keteraturan dalam diri sendiri maupun diri orang lain. Dengan kata lain, pendidikan tidak hanya dimaknai sebagai transfer pengetahuan, tetapi sebuah proses pengembangan berbagai macam potensi yang ada dalam diri manusia, seperti kemampuan akademis, relasional, bakat-bakat, talenta, kemampuan fisik dan daya-daya seni.

Adapun istilah multikultural secara etimologi dibentuk dari kata multi yang berarti banyak dan kultur yang berarti budaya (Mahfud, 2016, p. 75). Jadi multikultural secara sederhana dapat dimaknai sebagai banyak budaya. Menurut Tilaar (2002), multi di sini dapat berarti plural. Yang mana istilah plural mengandung arti yang berjenis-jenis, karena pluralisme bukan berarti sekedar pengakuan akan adanya hal-hal yang berjenisjenis, tetapi pengakuan tersebut juga mempunyai implikasi politik, sosial, dan ekonomi. Ia menegaskan bahwa pluralisme berkaitan erat dengan prinsip-prinsip demokrasi. Parekh (1997) (Hanum \& Rahmadonna, 2010) yang membatasi pengertian multikulturalisme dalam tiga hal, yaitu: pertama, multikulturalisme berkenaan dengan budaya; kedua, merujuk pada keragam,an yang ada; dan ketiga, berkenaan dengan tindakan spesifik pada respon terhadap keragaman tersebut.

Dari beberapa pengertian tersebut dapat dipahami bahwa multikultural adalah serangkaian budaya yang beragam dan memiliki karakteristik yang berbeda-beda. Dengan demikian pendidikan multikultural dapat diartikan sebagai bentuk pendidikan yang menghargai berbagai bentuk budaya siswa dalam proses pembelajaran.

Andersen dan Cusher (1994) mendifinisikan pendidikan multikultural sebagai pendidikan mengenai keragaman budaya (Mahfud, 2016, p. 175). Banks \& Banks (2005, p. 3) menjelaskan pendidikan multikultural dengan menyatakan: 


\begin{abstract}
Multicultural education incoporates the idea that all student regardless of their gender and social class and their ethnic, racial, or culture characteristics ahould have an equal opportunity to learn in school. Another importhant idea in multicultural education is that some student, because of these characteritics, have a better chance to learn in schools as they are currently structured than do student who belong to other groups or who have different cultural charactersitics.
\end{abstract}

Dengan demikian, pendidikan multikultural berusaha menggabungkan semua siswa tanpa membedakan jenis kelamin, kelas sosial, etnis, ras, atau karakteristik budaya. Semua siswa memiliki kesempatan yang sama untuk belajar di sekolah. Ide penting lain dalam pendidikan multikultural ini adalah beberapa siswa memiliki kesempatan yang lebih untuk belajar di sekolah meskipun memiliki karakteristik budaya yang berbeda. Banks menambahkan bahwa pendidikan multkultural dapat muncul dalam banyak wacana, program, dan praktik, tergantung pada kebutuhan, tuntutan dan aspirasi masyarakat yang beragam (Wulandari, 2016, p. 188).

Pendapat lain, dikemukakan oleh Howard (1993) yang menjelaskan bahwa pendidikan multikultural dapat memberi komptensi multikultural (Hanum \& Rahmadonna, 2010 , p. 93). Penjelasan ini mengandung pengertian bahwa dengan melaksanakan pendidikan multikultural dapat memberikan pehamaman tentang keragaman budaya. Dengan demikian, pendidikan multikultural sangat penting untuk diberikan kepada anak sejak usia dini.

\section{Tujuan Pendidikan Multikultural}

Pendidikan multikultural adalah maudel pendidikan yang dimaksudkan untuk menanamkan nilai-nilai multikultural atau keragaman budaya. Melalui pendidikan multikultural diharapkan anak-anak memiliki sikap saling menghargai satu dengan yang lain, tanpa membedakan ras, suku, agama, maupun kebudayaan. Menurut Skeel (1995) (Thohari, 2010, p. 70) tujuan pendidikan multikultural di sekolah adalah: (1) untuk memfungsikan peranan sekolah dalam memandang keberadaan siswa yang beraneka ragam; (2) untuk membantu siswa dalam membangun perlakukan yang positif terhadap perbedaan kultur, ras, etnik, kelompok keagamaan; (3) untuk memberikan ketahanan siswa dengan cara mengajar mereka dalam mengambil keputusan dan keterampilan sosialnya; dan (4) untuk membantu siswa dalam membangun ketergantungan lintas budaya dan memberi gambaran positif kepada mereka mengenai perbedaan kelompok.

Di samping itu, Banks menambahkan bahwa tujuan dari pendidikan multikultural adalah semua anak harus memiliki kesempatan yang sama untuk mendapatkan pendidikan terlepas dari adanya perbedaan jenis kelamin, ras, kelas sosial, maupun bahasa (Alismail, 2011, p. 141). Hanum \& Rahmadonna (2010, p. 93) menjelaskan bahwa tujuan utama pendidikan multikultural adalah mengubah pendekatan pembelajaran dan pembelajaran ke arah memberi peluang yang sama pada setiap anak. Dari uaraian ini nampak jelas bahwa tujuan pendidikan multikultural pada intinya ialah menanamkan sikap menghargai keragaman budaya dan memberikan kesempatan yang sama kepada anak-anak dalam mendapatkan hak-haknya dalam pendidikan.

\section{Nilai-nilai Pendidikan Multikultural}

Menurut pandangan Farida Hanum sebagaimana dikutip (Fransiska, 2016, p. 27) terdapat tiga nilai-nilai ini dalam pendidikan multikultural, yaitu sebagai berikut. Pertama, nilai demokratis. Nilai demokratis atau keadilan merupakan sebuah istilah yang menyeluruh dalam segala bentuk, baik keadilan budaya, politik, maupun sosial. Kedua, nilai humanis. Nilai humanisme atau kemanusia manusia adalah pengakuan atas pluralitas, heterogenitas, dan keragaman manusia, baik berupa ideologi, agama, paradigma, suku bangsa, pola pikir, kebutuhan, dan tingkat ekonomi. Ketiga, nilai pluralisme. Nilai pluralisme bangsa adalah pandangan yang mengakui adanya keragaman dalam suatu bangsa, seperti yang ada di Indonesia.

\section{Dimensi Pendidikan Multikultural}

Dalam bukunya Multicultural Education; Issue and Perspective, Banks \& Banks (2005, pp. 20-22) menyebutkan ada lima dimensi dalam pendidikan multikultural, di antaranya sebagai berikut. Pertama, content in- 
tegration (integrasi konten). Maksudnya ialah dalam pembelajaran guru menggunakan contoh dan bagian penting dari berbagai budaya dan kelompok untuk mengilustrasikan konsep-konsep dasar, prinsip, generalisasi, dan teori-teori dalam disiplin ilmu. Kedua, The knowledge construction process (proses kontruksi pengetahuan). Maksudnya guru membantu mengkonstruksikan pengetahuan siswa, sehingga mampu memahami dan menyelidiki dalam menentuka asumsi-asumsi tentang budaya menurut perspektif masing-masing. Ketiga, prejudice reduction (pengurangan prasangka). Menguraikan pelajaran dan kegiatankegiatan di mana guru membantu siswa mengembangkan sikap positif terhadap kelompok ras, etnis, dan budaya yang berbeda. Keempat, an equity pedagogy (kesetaraan pedagogi). Maksudnya guru dapat melakukan analisis terhadap prosedur dan cara pengajaran yang dilakukan untuk menggambarkan sikap multikultural dengan cara memfasilitasi siswa dari berbagai ras, budaya, gender, dan kelompok kelas sosial. Kelima, an empowering school culture (pemberdayaan budaya sekolah). Maksudnya pendidikan multikultural dimaksudkan untuk memberdayakan dan memperkenalkan berbagai budaya di sekolah, seperti jenis kelamin, ras, maupun berbagai kesenjangan kelas sosial.

Adapun implementasi dari dimensi pendidikan multikultural tersebut di Taman Kanak-Kanak yaitu dapat dilakukan guru dalam aktivitas belajar sehari-hari. Guru dapat mengenalkan anak dengan berbagai kebudayaan yang ada di Indonesia secara sederhana. Selain itu, dapat dilakukan guru dengan kegiatan-kegiatan sederhana, seperti berbagi makanan, bergantian dalam menggunakan mainan, dan menyayangi semua teman-taman di kelas. Dengan cara seperti itu, sesungguhnya secara tidak langsung dapat menanamkan konsep-konsep dan nilai-nilai pendidikan multikultural pada anak usia dini.

\section{Kurikulum Pendidikan Multikultural di Taman Kanak-Kanak}

Landasan Pengembangan Kurikulum Pendidikan Multikultural

Dalam pengembangan kurikulum pendidikan multikultural di Taman KanakKanak terdapat landasan-landasan yang harus diperhatikan dan dijadikan sebagai dasar dalam pengembangan kurikulum tersebut. Adapun landasan dalam pengembangan kurikulum pendidikan multikultural di Taman Kanak-Kanak adalah:

1) Landasan filosofis

Landasan filosofis merupakan landas-

an dalam pengembangan kurikulum yang lebih menekankan pada hakikat, tujuan, dan makna dari kurikulum pendidikan multikultural di Taman Kanak-Kanak. Artinya, sebelum mengembangkan kurikulum pendidikan multikultural harus dipahami terlebih dahulu apa pendidikan multikultural, tujuan, manfaat, maupun nilai-nilai yang terkandung di dalamnya.

\section{2) Landasan psikologis}

Landasan psikologis dimaksudkan bahwa dalam pengembangan kurikulum pendidikan multikultural di Taman Kanak-Kanak harus memperhatikan berbagai karakteristik maupun kejiwaan anak-anak usia dini. Dengan kata lain, kurikulum yang dikembangkan harus disesuaikan dengan kemampuan dan karakteristik anak usia dini, mulai dari materi sampai pada program-program yang ditawarkan dalam pembelajaran di sekolah.

3) Landasan sosiologis

Landasan ini dimaksudkan bahwa dalam pengembangan kurikulum pendidikan multikultural di Taman Kanak-Kanak harus disesuaikan dengan kebutuhan dan kondisi masyarakat setempat. Bisa jadi melihat muatan lokal setempat untuk dimasukkan dalam kurikulum sekolah. Intinya kurikulum yang dikembangkan jangan sampai merugikan orang tua dan masyarakat sekitar.

Prinsip-prinsip Pengembangan Kurikulum Pendidikan Multikultural

Menurut Subandiyah (1996) (Sujiono, 2009, p. 200) menyebutkan ada tujuh prinsip dalam pengembangan kurikulum pendidikan anak usia dini. Di mana prinsip-prinsip tersebut juga dapat dijadikan dasar dalam pengembangan kurikulum pendidikan multikultural di Taman Kanak-Kanak. Adapun prinsip-prinsip pengembangan kurikulum yang dimaksud adalah: (1) prinsip relevansi, bahwa kurikulum anak usia dini harus relevan dengan kebutuhan dan perkembangan anak secara individual; (2) prinsip adaptasi, bahwa kurikulum anak usia dini harus memperhati- 
kan dan mengadaptasi perubahan ilmu, teknologi, dan seni yang berkembang di masyarakat, termasuk perubahan sebagai akibat dari dampak psikososial; (3) prinsip kontinuitas, bahwa kurikulum anak usia dini harus disusun secara berkelanjutan antara satu tahapan perkembangan ke tahapan perkembangan berikutnya, sehingga harapannya anak siap memasuki pendidikan selanjutnya; (4) prinsip fleksibilitas, bahwa kurikulum anak usia dini harus dapat dipahami, dipergunakan, dan dikembangkan secara luwes sesuai dengan keunikan dan kebutuhan anak serta kondisi di mana pendidikan itu berlangsung; (5) prinsip kepraktisan, bahwa kurikulum anak usia dini harus dapat memberikan kemudahan bagi praktisi dan masyarakat dalam melaksanakan kegiatan pendidikan anak usia dini; (6) prinsip kelayakan, bahwa kurikulum anak usia dini harus menunjukkan kelayakan dan keberpihakan pada anak usia dini; (7) prinsip akuntabilitas, bahwa kurikulum anak usia dini yang dikembangkan harus dapat dipertanggungjawabkan pada masyarakat sebagai pengguna jasa pendidikan anak usia dini.

Berdasarkan paparan tersebut, sekilas dapat dipahami bahwa prinsip-prinsip tersebut sangat relevan dengan adanya pendidikan multikultural. Hal ini dikarenakan, pendidikan multikultural sudah menjadi tuntutan dan kebutuhan masyarakat, sehingga para orang tua anak sangat menghendaki adanya pengenalan pendidikan multikultural sejak usia dini. Harapannya setelah selesai menempuh sekolah di Taman Kanak-Kanak, anak-anak sudah memiliki bekal yang cukup tentang pendidikan multikultural.

\section{Pendekatan Pengembangan Kurikulum} Pendidikan Multikultural

Banks \& Banks (2005) mengemukakan empat pendekatan yang mengintegrasikan materi pendidikan multikultural ke dalam kurikulum ataupun pembelajaran di sekolah. Di mana keempat pendekatan tersebut secara sekilas dapat diimplementasikan dalam dunia pendidikan di Indonesia. Adapun pendekatan dalam pengembangan kurikulum pendidikan multikultural yaitu sebagai berikut.

Pertama, Pendekatan kontribusi (the contributions approach). Pendekatan kontribusi merupakan pendekatan pengembangan kurikulum yang dilakukan dengan memasukkan pahlawan-pahlawan dari suku bangsa/ etnis dan benda-benda budaya ke dalam mata pelajaran yang sesuai. Pendekatan ini dianggap yang paling ringan dan mudah untuk diimplementasikan dalam pendidikan.

Dalam kurikulum maupun pembelajaran di Taman Kanak-Kanak, tema-tema pembelajaran dapat dimasukkan kisah-kisah para pahlawan maupun tokoh-tokoh daerah yang memiliki yang memilki prestasi yang membanggakan, serta memperkenalkan kebudayaan-kebudayaan yang ada di Indonesia kepada anak-anak. Tema-tema yang dapat dimasuki dikembangkan melalui pendekatan kontribusi ini, di antaranya disajikan pada Tabel 1.

Kedua, pendekatan aditif (aditive approach). Pengembangan kurikulum dengan pendekatan ini yaitu dengan menambahkan materi, konsep, dan perspektif terhadap kurikulum tanpa mengubah struktur, tujuan, dan karakteristik dasarnya. Pedengan aditif ini lebih dilengkapi dengan penambahan buku, modul atau bidang bahasan terhadap kurikulum tanpa mengubahnya secara substantif.

Pengembangan dengan model pendekatan aditif ini, untuk jenjang Taman KanakKanak masih bisa dilakukan, yaitu dengan menambahkan tema-tema insindetal dalam suatu kegiatan, misalnya: kartian, peringatan hari besar agama, dan peringatan kemerdekaan Indonesia. Pengembangan ini dapat disajikan pada Tabel 2.

Tabel 1. Pengembangan Kurikulum Multikultural di Taman Kanak-Kanak dengan Pendekatan Kontribusi

\begin{tabular}{lll}
\hline No. & Tema Pembelajaran & Materi Pendidikan Multikultural \\
\hline 1. & Lingkunganku & Mengenalkan tempat ibadah masing-masing kepercayaan \\
2. & Kebutuhanku & Mengenalkan makanan dan pakaian dari masing-masing daerah. \\
3. & Rekreasi & Mengunjungi tempat-tempat bersejarah, misal: candi, rumah adat, atau yang lain \\
4. & Pekerjaanku & Menyebutkan pekerjaan-pekerjaan orang tua anak-anak. \\
5. & Tanah airku & Menyebutkan adat istiadat berbagai daerah kepada anak-anak. \\
\hline
\end{tabular}


Tabel 2. Pengembangan Kurikulum Pendidikan Multikultural di Taman Kanak-Kanak dengan Pendekatan Aditif

\begin{tabular}{cll}
\hline No. & Tema Insendental & Materu Pendidikan Multikultural \\
\hline 1. & Peringatan Kemerdekaan & Memperkenalkan anak-anak dengan pahlawan. \\
\hline 2. & Hari besar agama & Mengadakan kegiatan agama, bakti sosial, atau santunan. \\
\hline 3. & Kartinian & Meminta anak-anak memakai baju adat masing-masing daerah. \\
\hline
\end{tabular}

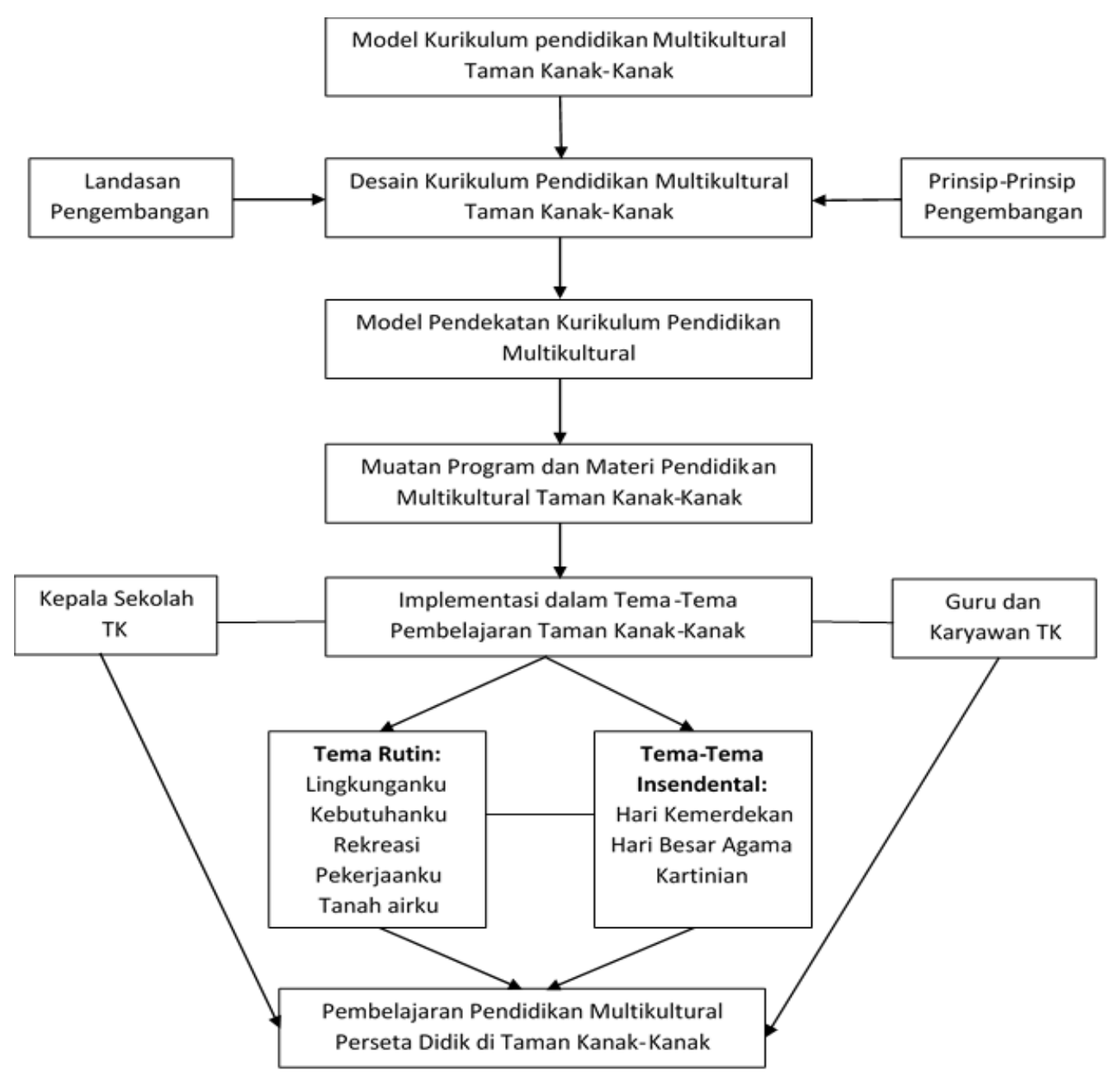

Gambar 1. Model Pengembangan Kurikulum Pendidikan Multikultural di Taman KanakKanak

Ketiga, pendekatan tranformatif (the transformation approach). Pendekatan transformasi berbeda secara mendasar dengan pendekatan kontribusi dan aditif. Letak perbedaannya yaitu pada pendekatan ini mengubah asumsi dasar kurikulum dan menumbuhkan kompetensi siswa dalam melihat konsep, isu, tema, dan problem dari beberapa perspektif dan sudut pandang etnis.

Dalam pendekatan transformatif ini, pengembangan kurikulum di Taman Kanak-
Kanak sudah mulai sulit diterapkan, karena anak-anak belum mampu berpikir secara rasional dengan baik. Oleh karenannya, pendekatan ini kurang cocok diaplikasikan pada pendidikan Taman Kanak-Kanak.

Ketiga, Pendekatan aksi sosial (the Social Action Approach). Pendekatan aksi sosial merupakan pendekatan yang paling sulit untuk diaplikasikan dalam kegiatan pembelajaran. Pendekatan ini mencakup semua elemen dari pendekatan transformasi, namun me- 
nambah komponen yang mempersyaratkan siswa membuat aksi yang berkaitan dengan konsep, isu atau masalah yang dipelajari dalam unit. Tujuan utama dari pendekatan aksi sosial ini adalah mendidik siswa melakukan untuk kritik sosial dan mengajari mereka keterampilan membuat keputusan.

Pendekatan aksi sosial ini, belum dapat diterapkan dalam pendidikan Taman Kanak-Kanak. Yang dalam pendekatan ini menuntu anak harus bisa berpikir kritis dan memiliki keterampilan mengambik keputusan, sedangkan anak usia dini belum mampu melakukan hal tersebut. Anak usia dini rasa ingin tahunya baru sebatas bertanya dan belum dapat memberikan komentar atau kritik terhadap sesuatu.

Berbagai landasan, prinsip, dan pendekatan dalam pengembangan kurikulum pendidikan multikultural di Taman Kanak-Kanak tersebut, secara konseptual dapat digambarkan melalui model pengembangan kurikulum yang disajijkan pada Gambar 1.

Model pengembangan kurikulum pendidikan multikultural di Taman Kanak-Kanak tersebut merupakan hipotesis awal yang masih membutuhkan kajian dan penelitian lebih lanjut. Model tersebut dikembangkan berdasarkan teori-teori yang telah dipaparkan di atas. Hipotesis model pengembangan kurikulum pendidikan multikultural di Taman Kanak-Kanak tersebut perlu diuji melalui penelitian pengembangan (R\&D) supaya dapat diketahui kelayakan dan efektivitasnya dalam pembelajaran anak usia dini di Taman KanakKanak.

\section{SIMPULAN}

Dari pembahasan di atas dapat disimpulkan bahwa: (1) konsep kurikulum pendidikan multikultural di Taman Kanak-Kanak dimaknai sebagai bentuk kurikulum yang memuat materi-materi pendidikan multikultural yang diperuntukkan bagi pembelajaran anak usia dini. Di mana tujuannya ialah untuk mengenalkan dan menanamkan anak usia dini sikap kebersamaan, keadilan, dan toleransi. (2) model pengembangan kurikulum pendidikan multikultural di Taman Kanak-Kanak dilakukan dengan meperhatikan landasan, prinsip, dan pendekatan pengembangan kurikulum pendidikan multikultural. Adapun model pendekatan yang dapat digunakan dan di- implementasikan dalam pendidikan Taman Kanak-Kanak yaitu pendekatan kontribusi dan aditif.

\section{Saran}

Dari kesimpulan di atas, saran yang dapat menjadi pertimbangan adalah dalam pengembangan kurikulum pendidikan multikultural sebaiknya menyesuaikan dengan tema dan sumber belajar yang terdekat dengan sekolah, sehingga tidak membebani sekolah, orang tua, maupun anak yang bersangkutan. Selain itu, dibutuhkan kreativitas dan kesungguhan dari guru dalam pengembangan kurikulum pendidikan multikultural di Taman Kanak-Kanak.

\section{DAFTAR PUSTAKA}

Alismail, H. A. (2011). Multicultural education: teachers' perceptions and preparation. Journal of Education and Practice, 7(11).

Arifin, Z. (2014). Konsep dan model pengembangan kurikulum. Bandung: Rosdakarya.

Banks, J. A., \& Banks, C. A. M. (Eds.). (2005). Multicultural education: issues and perspectives. New York: John Wiley and Sons.

Depdiknas. Undang-Undang Nomor 20 Tahun 2003 tentang Sistem Pendidikan Nasional (2003). Jakarta.

Fadlillah, M. (2014). Implementasi Kurikulum 2013 dalam pembelajaran SD/MI, SMP/MTS, dan SMA/MA. Yogyakarta: Ar-Ruzz Media.

Fransiska. (2016). Pendidikan multikultural di TK Mutiara Persada Soragan Yogyakarta. Yogyakarta: Tesis Program Pascasarjana UNY.

Hamalik, O. (2007). Kurikulum dan Pembelajaran. Jakarta: Bumi Aksara.

Hanum, F., \& Rahmadonna, S. (2010). Implementasi model pembelajaran multikultural di sekolah dasar propinsi Daerah Istimewa Yogyakarta. JURNAL PENELITIAN ILMU PENDIDIKAN, 3(1). https://doi.org/10.21831/JPIPFIP.V0I0.4 
629

Hidayat, S. (2013). Pengembangan kurikulum baru. Bandung: Rosdakarya.

Koesoema, D. (2011). Pendidikan karakter: strategi mendidik anak di zaman global. Jakarta: Grasindo.

Mahfud, C. (2016). Pendidikan multikultural. Yogyakarta: Pustaka Pelajar.

Mendikbud. Peraturan Menteri Pendidikan dan Kebudayaan Nomor 146 Tahun 2014 tentang Kurikulum 2013 PAUD (2014).

Rusman. (2011). Manajemen kurikulum. Jakarta: Raja Grafindo Persada.

Sanjaya, W. (2008). Kurikulum dan pembelajaran. Jakarta: Kencana Prenada Media Group.

Sugiyono. (2011). Metode penelitian kuantitatif, kualitatif dan $R \& D$. Bandung: Alfabeta.

Sujiono, Y. N. (2009). Konsep dasar pendidikan anak usia dini. Jakarta: Indeks.

Sutrisno. (2011). Pembaharuan dan Pengembangan Pendidikan Islam. (Fadilatama, Ed.). Yogyakarta:

Thohari, A. (2010). Model pendidikan multikultural di keluarga, sekolah, dan masyarakat kecamatan Sungai Ambawang. Yogyakarta: Disertasi Program Pascasarjana UNY.

Wahyudin, U., \& Agustin, M. (2011). Penilaian perkembangan anak usia dini. Bandung: Refika Aditama.

Wulandari, T. (2016). Rekayasa sosial kolaborasi pendidikan karakter dan pendidikan multikultural: Praksis di yayasan perguruan Sultan Iskandar Muda. Jurnal Pembangunan Pendidikan: Fondasi Dan Aplikasi, 4(2), 186.

https://doi.org/10.21831/jppfa.v4i2.1242 4 